Wahyu Budianto Dan Payamta : Pengaruh Kepemilikan Manajerial Terhadap ...

\title{
PENGARUH KEPEMILIKAN MANAJERIAL TERHADAP NILAI PERUSAHAAN DENGAN KEBIJAKAN DIVIDEN SEBAGAI VARIABEL MODERASI
}

\author{
Wahyu Budianto dan Payamta \\ Magister Akuntansi Universitas Sebelas Maret Surakarta \\ Email: parcher9@yahoo.com
}

\begin{abstract}
ABSTRAK
Penelitian ini bertujuan menguji pengaruh kepemilikan manajerial terhadap nilai perusahaan dengan kebijakan dividen sebagai variabel moderasi pada perusahaan manufaktur yang terdaftar di Bursa Efek Indonesia. Sampel diambil dengan metoda puposive sampling. Hipotesis dalam penelitian ini diuji menggunakan uji regresi dengan variabel moderasi. Hasil penelitian ini menunjukkan bahwa; 1) kepemilikan manajerial berpengaruh negatif terhadap nilai perusahaan. 2) kebijakan dividen merupakan variabel moderasi dalam hubungan antara kepemilikan manajerial dan nilai perusahaan.
\end{abstract}

Kata Kunci: kepemilikan manajerial, kebijakan dividen, nilai perusahaan, moderasi.

\section{PENDAHULUAN}

Perusahaan didirikan dengan tujuan meningkatkan nilai perusahaan sehingga dapat memberikan kemakmuran bagi pemilik (Siallagan dan Machfoedz, 2006). Jensen (1986) menyebutkan bahwa teori keagenan menjelaskan bahwa pemegang saham sebagai prinsipal mendelegasikan tugas dan wewenang kepada manajemen sebagai agen untuk mengelola perusahaan. Pemegang saham sebagai pemilik perusahaan berada diluar perusahaan sehingga tidak dapat sepenuhnya mengawasi kinerja perusahaan. Manajemen berada dalam perusahaan sehingga lebih mengetahui akan kondisi perusahaan yang sesungguhnya. Hal ini menyebabkan terjadinya konflik keagenan yang disebabkan karena informasi yang tidak simetri antara manajemen dan pemegang saham.

Kepemilikan manajerial adalah kepemilikan saham oleh pihak manajemen perusahaan. Kepemilikan saham manajerial dapat digunakan untuk mensejalankan antara kepentingan pemegang saham dengan manajer. Sebagai pemilik perusahaan manajer akan ikut merasakan langsung manfaat dari keputusan yang diambil dan manajer ikut menanggung risiko apabila ada kerugian yang timbul sebagai konsekuensi dari pengambilan keputusan yang salah. Semakin besar proporsi kepemilikan manajemen pada perusahaan akan dapat menyatukan kepentingan antara manajer dengan pemegang saham, sehingga diharapkan dapat meningkatkan nilai dan kinerja perusahaan (Jensen, 1986).

Soliha dan Taswan (2002) menemukan hubungan yang signifikan dan positif antara kepemilikan menajerial dan nilai perusahaan, sedangkan hasil penelitian Benson dan Davinson (2008) menunjukkan hasil yang negatif antara kepemilikan manajerial dan nilai perusahaan. Kepemilikan manajerial yang besar dianggap memperbesar perilaku oportunis manajer sehingga pasar akan bereaksi negatif yang berdampak pada penurunan nilai perusahan (Benson dan Davinson, 2008).

Salah satu faktor yang diduga berpengaruh terhadap nilai perusahan adalah kebijakan dividen (Olweny, 2012). Iturriaga dan Crisóstomo (2010) menjelaskan keputusan tentang dividen mengundang perdebakatan dikalangan peneliti keuangan. Abdullah et al., (2012) menyatakan bahwa kebijakan dividen merupakan salah satu isu kontroversial dibidang keuangan yang menarik untuk diteliti. Dividen merupakan pembayaran perusahan kepada pemegang saham. Kebijakan dividen biasanya dilakukan setelah perusahaan menghasilkan laba. Kebijakan 
dividen bukan merupakan beban bagi perusahaan melainkan sharing asset perusahaan kepada pemegang saham. Penelitian telah mencoba mencari penjelasan tentang mengapa perusahaan membayar dividen, salah satunya adalah sinyal kepada pihak eksternal akan nilai perusahaan. Solong dan Nor (2010) menyebutkan bahwa dividen akan meningkatkan nilai perusahaan. Keberadaan dividen dapat meningkatkan komunikasi dan kordinasi masalah dalam perusahaan sehingga dapat mengurangi biaya keagenan dan meningkatkan nilai perusahaan.

Penelitian ini akan melakukan pengujian tentang pengaruh kepemilikan manajerial terhadap nilai perusahaan dengan kebijakan dividen sebagai variabel moderasi. Pengujian kepemilikan manajerial terhadap nilai perusahaan dilatarbelakangi oleh belum konklusifnya hasil penelitian sebelumnya dimana ada yang menunjukkan pengaruh positif (Soliha dan Taswan, 2002), serta ada yang memberikan hasil negatif seperti hasil penelitian Benson dan Davinson (2008). Olweny (2012) mengemukakan adanya pengaruh kebijakan dividen terhadap nilai perusahaan, hasil yang senada diungkap oleh Abdullah et al., (2012) yang menjelaskan adanya keterkaitan kebijakan dividen dan nilai perusahaan. Jensen dan Meckling (1976) menjelaskan bahwa dividen merupakan salah satu kebijakan yang dilakukan untuk mengatasi masalah keagenan dalam perusahaan. Hal ini mengundang pemikiran peneliti bahwa kebijakan dividen yang diambil oleh manajemen dapat mempengaruhi reaksi pasar terhadap adanya kepemilikan manajerial dalam perusahaan. Berdasar hal tersebut maka dalam penelitian ini peneliti akan mencoba memberikan bukti empiris tentang peran kebijakan dividen sebagai variabel moderasi dalam hubungan antara kepemilikan manajerial dan nilai perusahaan.

\section{TINJAUAN PUSTAKA DAN PENGEMBANGAN HIPOTESIS}

Adanya pemisahan antara fungsi kepemilikan dan fungsi pengendalian dalam hubungan keagenan sering menimbulkan masalah-masalah keagenan (agency problems). Masalah-masalah keagenan tersebut timbul karena adanya konflik atau perbedaan kepentingan antara principal (pemilik perusahaan atau pihak yang memberikan mandat) dan agent (manajer perusahaan atau pihak yang menerima mandat). Teori keagenan berusaha menjelaskan tentang penentuan kontrak yang paling efisien yang bisa membatasi konflik atau masalah keagenan (Jensen dan Meckling, 1976).

Almilia dan Sifa (2006) menyatakan bahwa perusahaan didirikan dengan tujuan meningkatkan nilai perusahaan melalui peningkatan kemakmuran pemilik atau para pemegang saham. Namun dilain pihak manager sebagai pengelola perusahaan mempunyai tujuan yang berbeda terutama dalam hal peningkatan prestasi individu dan kompensasi yang akan diterima. Jika manager perusahaan melakukan tindakan-tindakan yang mementingkan diri sendiri dengan mengabaikan kepentingan investor, maka akan menyebabkan jatuhnya harapan para investor tentang pengembalian (return) atas investasi yang telah mereka tanamkan. Oleh karenanya dibutuhkan adanya suatu perlindungan terhadap berbagai pihak yang berkepentingan dengan perusahaan tersebut.

Manajer dan pemegang saham selalu berbeda kepentingan, yang dikenal dengan konflik keagenan (Jensen, 1986). Konflik keagenan akan mempengaruhi kedua pihak untuk memaksimalkan kesejahteraannya masing-masing. Kekhawatiran pemegang saham berkaitan dengan kendali atas sumber daya perusahaan yang dipegang oleh manajer, sehingga ada kemungkinan manajer akan mengambil keputusan yang merugikan pemegang saham atau melakukan tindakan-tindakan yang memanfaatkan sumber daya perusahaan untuk kesejahteraannya sendiri. Pemegang saham berusaha mengatasi masalah tersebut dengan melakukan pengawasan terhadap manajer (Jensen and Meckling, 1976). Ngui et al (2007) menyatakan bahwa komposisi struktur kepemilikan yang optimal akan berpengaruh terhadap kinerja perusahaan. Struktur kepemilikan diproksikan dengan kepemilikan oleh blockholder dan kepemilikan oleh insider. Struktur kepemilikan yang tepat diharapkan dapat 
Wahyu Budianto Dan Payamta : Pengaruh Kepemilikan Manajerial Terhadap ...

menıngkatkan kınerja perusahaan. Kınerja perusanaan yang menıngkat akan dıkutı oleh kenaikan harga saham perusahaan yang menunjukkan investor memberikan penilaian yang tinggi terhadap peningkatan kinerja perusahaan.

Olweny (2012) mencoba menjelaskan hubungan antara kepemilikan manajerial dan nilai perusahaan dari sisi the contracting theory approach. Menurut teori ini prosentase kepemilikan manajerial yang optimal untuk mengatasi masalah keagenan. Pemilik perusahaan memberi kompensasi kepada manajer dalam bentuk kepemilikan saham agar pemikiran sejalan dan nilai perusahaan selalu dicoba untuk dioptimalkan bagi kesejahteraan pemegang saham. Hal yang perlu dilakukan oleh pemegang saham adalah membentuk komposisi kepemilikan manajerial yang optimal akan dapat meningkatkan nilai perusahaan.

Pendapat yang berbeda diungkapkan oleh Lee dan Ryu (2003). Lee dan Ryu (2003) menyatakan bahwa struktur kepemilkan merupakan negatif potensial yang dapat mempengaruhi nilai perusahaan. Adanya asimetri informasi antara manajemen perusahaan dengan outsider memungkinkan adanya biaya transaksi yang tinggi bagi outsider. Masuknya pihak manajemen sebagai pemilik saham perusahaan diasumsikan akan mengurangi resiko outsider karena pihak manajemen ikut menanggung resiko akan perusahaan nilai perusahaan. Haruman (2008) menunjukan bahwa variabel managerial ownership memiliki pengaruh dengan nilai perusahaan dengan arah hubungan negatif. Penurunan nilai perusahaan ini diakibatkan karena tindakan oportunistik yang dilakukan oleh para pemegang saham managerial. Kepemilikan managerial menginginkan pendapatan yang tinggi dibandingkan dengan pertumbuhan investasi perusahaanya, sehingga apabila kepemilikan manajerial tinggi maka akan cenderung pasar bereaksi negatif yang menyebabkan nilai perusahaan turun.

Wardhani (2006) menyatakan bahwa apabila struktur kepemilikan perusahaan dimiliki oleh dewan direksi atau dewan komisarisnya maka dewan tersebut justru akan cenderung melakukan tindakan-tindakan ekspropriasi yang menguntungkannya secara pribadi. Oleh karena itu dengan kepemilikan perusahaaan dimiliki oleh direksi semakin meningkat maka keputusan yang diambil oleh direksi akan lebih cenderung untuk menguntungkan dirinya dan secara keseluruhan akan merugikan perusahaan sehingga kemungkinan nilai perusahaan akan cenderung mengalami penurunan.

Berdasar penjelasan di atas maka hipotesis yang diajukan dalam penelitian ini adalah sebagai berikut.

$\mathrm{H}_{1}$ : kepemilikan manajerial berpengaruh negatif terhadap nilai perusahaan

Iturriaga dan Crisóstomo (2010) menyebutkan bahwa teori sinyal dan teori arus kas bebas menjelaskan bahwa dividen mempengaruhi nilai perusahaan dengan mempertimbangkan ada atau tidaknya pertumbuhan dalam perusahaan. Perusahaan memberikan sinyal akan pertumbuhannya dengan cara membayar dividen. Peningkatan pembayaran dividen diharapkan memberikan pengaruh yang positif terhadap nilai perusahaan. Pembayaran dividen merupakan indikasi perusahaan yang profitable, memiliki prospek yang baik dimasa depan sehingga berpotensi bagi kesejahteraan investor dimasa depan. Jensen (1986) menyatakan bahwa salah satu masalah antara manajer dan pemegang saham yaitu pemegang saham lebih menyukai pembayaran dividen dari pada diinvestasikan lagi sementara manajer sebaliknya.

Barkaitan dengan kebijakan dividen, Haruman (2008) berpendapat kebijakan dividen merupakan corporate action yang penting yang harus dilakukan perusahaan kebijakan tersebut dapat menentukan berapa banyak keuntungan yang akan diperoleh pemegang saham. Keuntungan yang akan diperoleh pemegang saham ini akan menentukan kesejahteraan para pemegang saham yang merupakan tujuan utama perusahaan. Semakin besar dividen yang dibagikan kepada pemegang saham, maka kinerja emiten atau perusahaan akan dianggap semakin baik pula dan pada akhirnya perusahaan yang memiliki kinerja yang baik dianggap menguntungkan dan tentunya penilaian terhadap perusahaan tersebut akan semakin baik pula. 
Nilai perusahaan dapat dilihat dari kemampuan perusahaan membayar dividen. Ada saatnya dividen tersebut tidak dibagikan oleh perusahaan karena perusahaan merasa perlu untuk menginvestasikan kembali laba yang diperolehnya. Besarnya dividen tersebut dapat mempengaruhi harga saham. Apabila dividen yang dibayar tinggi, maka harga saham cenderung tinggi sehingga nilai perusahaan juga tinggi dan jika dividen dibayarkan kepada pemegang saham kecil maka harga saham perusahaan yang membagikannya tersebut juga rendah. Kemampuan sebuah perusahaan membayar dividen erat hubungannya dengan kemampuan perusahaan memperoleh laba. Jika perusahaan memperoleh laba yang tinggi, maka kemampuan perusahaan akan membayarkan dividen juga tinggi. Dengan dividen yang besar akan meningkatkan nilai perusahaan (Harjito dan Martono (2005) dalam Mahendara et al., (2012)).

Osman dan Muhammed (2010) mengemukaan bahwa pembayaran dividen berkaitan dengan teori sinyal. Sebagai agen, menejemen memberikan sinyal melalui laporan keuangan tentang kondisi perusahaan. Salah satu bentuk sinyal tersebut adalah pembayaran dividen. Pembayaran dividen yang meningkat dianggap sebagai sinyal yang baik akan kondisi perusahaan serta menunjukkan prospek akan profitabilitas perusahaan yang tinggi di masa depan. Hal ini berdampak pada peningkatan harga saham ketika perusahaan membagikan dividen meningkat dan menurunnya harga saham jika dividen yang dibayarkan menurun. Hal ini menunjukkan bahwa pembayaran dividen mempengaruhi nilai perusahaan.

Sulong dan Nor (2010) menyatakan bahwa perusahaan diharapkan membayar dividen lebih tinggi pada perusahaan yang memiliki komisaris independen yang lebih besar. Dividen merupakan bagian dari aba perusahaan yang dibagikan dalam rangka peningkatan kesejahteraan pemegang saham. Semakin sejahtera pemegang saham akan semakin tinggi nilai perusahaan. Atmaja (2009) menyatakan bahwa dividen dapat digunakan untuk mengendalikan pemegang saham perusahaan pada perusahaan dengan tipe kepemilikan terkonsentrasi. Perusahaan dengan dividen yang tinggi memiliki masalah keagenan yang lebih rendah jika dibandingkan dengan perusahaan dividen yang rendah.

$\mathrm{H}_{2}$ : kebijakan dividen memoderasi hubungan antara kepemilikan manajerial dan nilai perusahaan

\section{METODE PENELITIAN}

\section{Populasi, Sampel dan Data Penelitian}

Populasi dalam penelitian ini adalah seluruh perusahaan manufaktur yang terdaftar di Bursa Efek Indonesia. Penelitian ini menggunakan data sekunder dari laporan keuangan perusahaan manufaktur tahun 2008-2010 yang telah diaudit. Data harga saham perusahaan diperoleh melalui website yahoofinance. Data dalam penelitian ini diambil dengan metoda purposive sampling, dengan kriteria: 1) Perusahaan manufaktur, 2) Menerbitkan laporan keuangan auditan dengan tanggal 31 Desember, 3) Menerbitkan laporan keuangan dalam mata uang Rupiah, 4) Tidak de-listing selama tahun 2008-2010, 5) Memiliki data yang lengkap sesuai dengan kebutuhan peneliti. Data dalam penelitian ini dianalisis dengan menggunakan regresi linier berganda dengan bantuan software SPSS for Windows versi 15.0.

\section{Definisi Operasional Variabel}

\section{Variabel Independen}

Varibel independen dalam penelitian ini adalah kepemilikan manajerial. Chistiawan dan Tarigan (2004) menyebutkan bahwa kepemilikan manajerial adalah situasi dimana manajer memiliki saham perusahaan atau dengan kata lain manajer tersebut sekaligus sebagai pemegang saham perusahaan. Kepemilkan manajerial dalam penelitian ini diukur dengan prosentase kepemilikan saham oleh pihak manajer perusahaan. 


\section{Variabel Dependen}

Variabel dependen dalam penelitian ini adalah nilai perusahaan. Nilai dapat diartikan sebagai nilai perusahaan dihadapan investor. Nilai perusahaan dalam penelitian ini diproksikan dengan PBV (Siallagan dan Machfoed, 2006), yang dinotasikan dengan rumus:

Price to book ratio $=\frac{\text { harga per lembar saham }}{\text { nilai buku per lembar saham }}$

\section{Variabel Moderasi}

Variabel moderasi dalam penelitian ini adalah kebijakan dividen. Kebijakan dividen diukur dengan dummy kebijakan dividen dimana nilai 1 untuk perusahaan yang membayar dividen dan nilai 0 bagi perusahaan yang pada tahun tersebut tidak melakuan pembayaran dividen. Pengukuran ini didasarkan pada penelitian Osman dan Muhammed (2010).

\section{Variabel Kontrol}

Penelitian ini menggunakan dua variable kontrol yaitu ukuran perusahaan yang di ukur dengan log natural total aktiva perusahaan serta leverage yang merupakan rasio yang membandingkan antara total hutang dan total aktiva perusahaan (Wahyudi dan Pawestri, 2006).

\section{Uji Statistik}

\section{Analisis Deskriptif}

Statistik deskriptif digunakan untuk memberikan gambaran tentang distribusi data dalam penelitian ini. Statistik deskriptif meliputi rata-rata, minimum, maksimum serta standar deviasi yang bertujuan mengetahui distribusi data yang menjadi sampel penelitian.

\section{Uji Asumsi Klasik}

Model regresi maka terlebih dahulu akan dilakukan uji asumsi klasik yang meliputi beberapa pengujian uji Normalitas Data, Uji Multikolinieritas, Uji Autokorelasi dan Uji Heteroskedastisitas.

\section{Uji Regresi}

Hipotesis dalam penelitian ini diuji dengan model persamaan regresi. Persamaan regresi yang digunakan dalam penelitian ini adalah sebagai berikut.

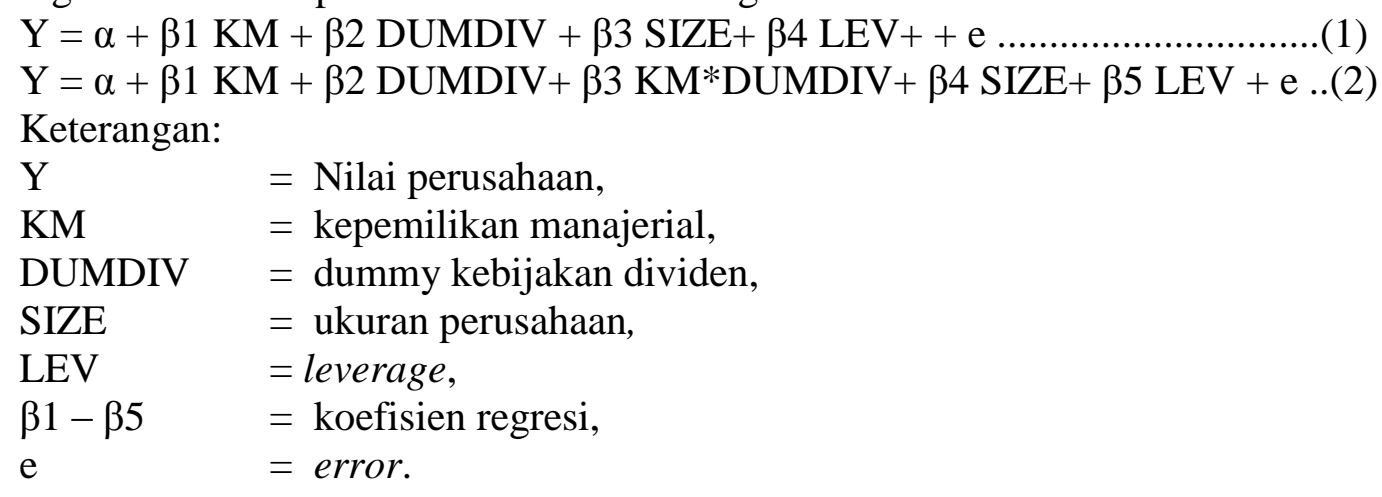

\section{ANALISIS DAN PEMBAHASAN Hasil Pengumpulan Data}

Penelitian ini bertujuan mengetahui pengaruh kepemilikan manajerial terhadap nilai perusahaan dengan kebijakan dividen sebagai variabel moderasi pada perusahaan manufaktur yang terdaftar di Bursa Efek Indonesia tahun 2008 sampai dengan 2010. Jumlah sampel tahun 2008 sampai dengan tahun 2010 sebanyak 309 perusahaan jenis industri manufaktur dengan sampel perusahaan di masing-masing tahun sebanyak 103 perusahaan. 


\section{Uji Asumsi Klasik}

\section{Uji Normalitas Data}

Uji normalitas data bertujuan mengetahui apakah data yang digunakan dalam penelitian telah terdistribusi dengan normal. Hasil uji normalitas tersaji pada tabel berikut ini.

\section{Tabel 1}

Uji Normalitas Data

\begin{tabular}{lllll}
\hline $\mathrm{N}$ & $\begin{array}{l}\text { Kolmogorov- } \\
\text { Smirnov Z }\end{array}$ & $\begin{array}{l}\text { Asymp. } \\
\text { Sig. (2-tailed) }\end{array}$ & Kriteria & Keterangan \\
\hline 309 & 4,342 & 0,000 & $>0,05$ & Tidak Normal \\
\hline
\end{tabular}

Sumber: Hasil Pengolahan Data

Hasil uji normalitas data dengan One-Sample Kolmogorov-Smirnov menunjukan bahwa nilai p sebesar 0,00, nilai tersebut di bawah 0,05, sehingga dapat disimpulkan bahwa data dalam penelitian ini tidak terdistribusi dengan normal. Oleh karena itu variabel yang digunakan dalam penelitian ini ditransformasi dengan menggunakan log natural. Uji normalitas data setelah dilakukan transformasi data tersaji pada tabel berikut ini.

\section{Tabel 2}

Uji Normalitas Data setelah Log

\begin{tabular}{lllll}
\hline $\mathrm{N}$ & $\begin{array}{l}\text { Kolmogorov- } \\
\text { Smirnov Z }\end{array}$ & $\begin{array}{l}\text { Asymp. } \\
\text { Sig. (2-tailed) }\end{array}$ & Kriteria & Keterangan \\
\hline 309 & 1,321 & 0,061 & $>0,05$ & Normal \\
\hline
\end{tabular}

Sumber: Hasil Pengolahan Data

Hasil uji normalitas data dengan One-Sample Kolmogorov-Smirnov menunjukan bahwa nilai p sebesar 0,061, nilai tersebut di atas 0,05, sehingga dapat disimpulkan bahwa data dalam penelitian ini telah terdistribusi dengan normal.

\section{Uji Multikolinieritas}

Multikolinieritas merupakan pengujian yang digunakan untuk mengetahui korelasi antar variabel independen. Keberadaan multikolinieritas dideteksi dengan Varians Inflating Factor (VIF) dan Tolerance (Ghozali 2005). Hasil uji multikolinieritas tersaji pada tabel berikut ini.

Tabel 3

Uji Multikolinieritas

\begin{tabular}{llll}
\hline Variabel & Tolerance & VIF & Keterangan \\
\hline KM & 0,661 & 1,513 & Tidak terdapat multikolinieritas \\
DUMDIV & 0,668 & 1,453 & Tidak terdapat multikolinieritas \\
LNSIZE & 0,776 & 1,288 & Tidak terdapat multikolinieritas \\
LNLEV & 0,875 & 1,143 & Tidak Terdapat multikolinieritas \\
KM*DUMDIV & 0,634 & 1,578 & Tidak terdapat multikolinieritas \\
\hline
\end{tabular}

Sumber: Hasil Pengolahan Data

Hasil uji multikolinieritas menunjukan bahwa dalam model regresi menunjukan nilai tolerance di atas $10 \%$ dan nilai VIF di bawah 10 sehingga dapat disimpulkan bahwa dalam model regresi tidak terdapat multikolinieritas.

\section{Uji Autokorelasi}

Hasil uji autokorelasi dengan Durbin Watson dapat dilihat pada tabel berikut ini.

\section{Tabel 4}

Uji Autokorelasi

\begin{tabular}{lll}
\hline D-W Hitung & Kriteria & Keterangan \\
\hline 1,812 & Mendekati +2 & Tidak terdapat autokorelasi \\
\hline
\end{tabular}

Sumber: Hasil Pengolahan Data 
Hasil uji autokorelasi dengan menggunakan uji Durbin Watson menunjukkan nilai D-W hitung sebesar 1,812. Hasil tersebut mendekati nilai +2 sehingga dapat disimpulkan bahwa dalam model regresi tidak terjadi autokorelasi.

\section{Uji Heteroskedastisitas}

Model regresi yang baik adalah yang homokedastisitas atau tidak heteroskedastisitas (Ghozali 2005). Uji heteroskedastisitas dalam penelitian ini diuji dengan Scaterplots (Ghozali 2005). Hasil uji heteroskedastisitas dapat dilihat pada gambar berikut ini.

\section{Gambar 1}

\section{Uji Heteroskedastisitas}

Scatterplot

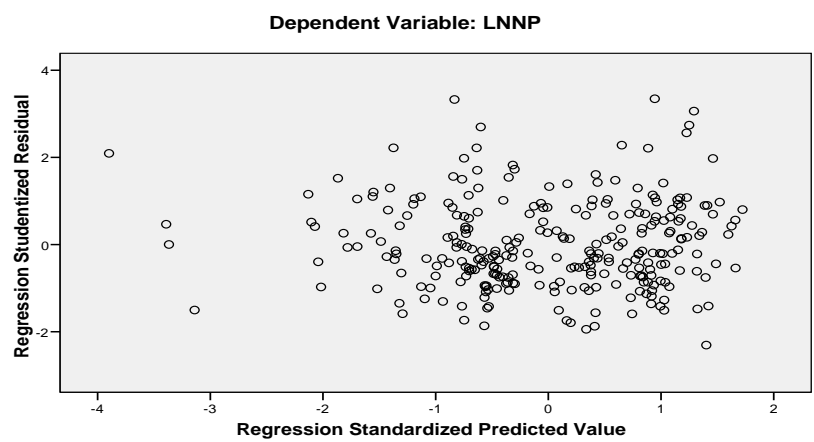

Hasil uji heteroskedastisitas menunjukan bahwa titik-titik tersebar di atas dan dibawah angka nol sehingga dapat disimpulkan bahwa dalam model regresi tidak terjadi heteroskedastisitas.

\section{Uji Hipotesis}

\section{Uji Hipotesis 1}

Hipotesis 1 dalam penelitian ini diuji dengan regresi persamaan 1. Regresi persamaan 1 menguji kepemilikan manajerial dan kebijakan dividen terhadap nilai perusahaan tanpa menggunakan variabel moderasi. Hasil pengujian regresi persamaan 1 meliputi beberapa analisis sebagai berikut.

a. Koefisien Determinasi

Hasil uji koefisien determinasi untuk regresi linier berganda yang digunakan dalam penelitian ini tersaji pada tabel berikut ini.

Tabel 5

Koefisien Determinasi 1

\begin{tabular}{lllll}
\hline $\mathbf{R}$ & R Square & $\begin{array}{l}\text { Adjusted } \\
\text { square }\end{array}$ & $\begin{array}{l}\text { R } \\
\text { of the estimate } \\
\text { ofdard error }\end{array}$ \\
\hline 0,362 & 0,131 & 0,119 & 0,927 \\
\hline
\end{tabular}

Sumber: Hasil Pengolahan Data

Dari tabel di atas diketahui bahwa koefisien determinasi menunjukkan nilai adjusted $R$ square sebesar 0,119 . Hal ini berarti $11,9 \%$ variasi perubahan nilai perusahaan dapat dijelaskan oleh kepemilikan manajerial, kebijakan dividen, leverage dan ukuran perusahaan, sisanya $88,1 \%$ perubahan nilai perusahaan dipengaruhi faktor lain diluar model penelitian. 
b. Nilai F

Hasil uji nilai F statistik tersaji pada tabel berikut ini.

Tabel 6

Nilai F Regresi 1

\begin{tabular}{|c|c|c|c|c|c|c|}
\hline $\begin{array}{l}\text { Mod } \\
\text { el }\end{array}$ & & $\begin{array}{l}\text { Sum of } \\
\text { Squares }\end{array}$ & $\mathrm{df}$ & $\begin{array}{l}\text { Mean } \\
\text { Square }\end{array}$ & $\mathrm{F}$ & Sig. \\
\hline \multirow[t]{3}{*}{1} & $\begin{array}{l}\text { Regressio } \\
n\end{array}$ & 36.068 & 4 & 9.017 & 10.490 & 0.000 \\
\hline & Residual & 238.957 & 278 & 0.860 & & \\
\hline & Total & 275.025 & 282 & & & \\
\hline
\end{tabular}

Sumber: Hasil Pengolahan Data

Nilai F regresi bertujuan untuk menguji tingkat fit model penelitian (Ghozali 2005). Hasil uji nilai $\mathrm{F}$ menunjukkan nilai $\mathrm{F}$ sebesar 10,49 dengan nilai $\mathrm{p}$ sebesar 0,000 , sehingga dapat disimpulkan bahwa model penelitian ini telah fit dengan data yang digunakan.

c. Nilai $\mathrm{t}$

Hasil uji nilai t statistik tersaji pada tabel berikut ini.

Tabel 7

Nilai t Regresi 1

\begin{tabular}{llllll}
\hline Variabel & $\begin{array}{l}\text { Koefisien } \\
\text { Regresi }\end{array}$ & $\begin{array}{l}\text { Standar } \\
\text { Error }\end{array}$ & $\begin{array}{l}\text { Koefisien } \\
\text { Korelasi }\end{array}$ & t hitung & Nilai p \\
\hline (Constant) & $-2,304$ & 1,002 & & & \\
KM & $-1,582$ & 0,610 & $-0,149$ & $-2,595$ & 0,010 \\
DUMDIV & 0,448 & 0,124 & 0,227 & 3,608 & 0,000 \\
LNSIZE & 0,075 & 0,091 & 0,049 & 0,825 & 0,410 \\
LNLEV & 0,075 & 0,036 & 0,131 & 2,071 & 0,039 \\
\hline
\end{tabular}

Sumber: Hasil Pengolahan Data

Hipotesis 1 dalam penelitian ini bertujuan untuk menguji pengaruh kepemilikan manajerial terhadap nilai perusahaan. Hasil uji regresi menunjukkan koefisien regresi sebesar sebesar -1,582 dengan nilai p sebesar 0,010. Uji regresi memberikan hasil yang signifikan, sehingga dapat disimpulkan bahwa kepemilikan manajerial berpengaruh negatif terhadap nilai perusahaan. Hasil penelitian mendukung hasil penelitian Haruman (2008) yang menemukan pengaruh negatif antara kepemilikan manajerial dan nilai perusahaan. Semakin besar kepemilikan manajerial dalam struktur pemegang saham akan menyebabkan rawan tindakan yang lebih mementingkan kepentingan manajer dari pada kepentingan pemegang saham, hal ini berdampak pada reaksi negatif pasar yang berdampak pada menurunnya nilai perusahaan. Kepemilikan manajerial yang besar dinilai rawan tindakan manajer yang oportunistik dan cenderung mementingkan kepentingan sendiri dibandingkan kepentingan pemegang saham yang diluar perusahaan.

Benson dan Davinson (2008) menyatakan bahwa kepemilikan manajerial berpengaruh negatif terhadap nilai perusahaan dengan penjelasan bahwa bila kepemilikan manajerial besar maka akan ada kecenderungan tindakan manajer yang oportunis dari manajer yang akan menguntungkan diri sendiri. Hal ini terjadi karena manajer mencoba melakukan transfer kekayaan perusahaan kepada diri sendiri dengan mengambil kebijakan yang membesarbesarkan aktiva dan laba. Tujuannya adalah untuk memperoleh bonus atau agar kinerjanya terlihat meningkat. Hal tersebut akan berdampak pada penurunan kinerja pasar yang pada akhirnya akan menurunkan nilai perusahaan. 


\section{Uji Hipotesis 2}

Uji hipotesis ke-2 menguji peran kebijakan dividen sebagai variabel moderasi dalam hubungan antara kepemilikan manajerial terhadap nilai perusahaan. Pengujian hipotesis ke-2 meliputi beberapa tahap pengujian sebagai berikut.

\section{a. Koefisien Determinasi}

Hasil uji koefisien determinasi untuk regresi linier berganda yang digunakan dalam penelitian ini tersaji pada tabel berikut ini.

Tabel 8

Koefisien Determinasi 2

\begin{tabular}{llll}
\hline $\mathrm{R}$ & R Square & $\begin{array}{l}\text { Adjusted } \\
\text { square }\end{array}$ & $\begin{array}{l}\mathrm{R} \\
\begin{array}{l}\text { Standard error } \\
\text { of the estimate }\end{array}\end{array}$ \\
\hline 0,374 & 0,140 & 0,124 & 0,924 \\
\hline
\end{tabular}

Sumber: Hasil Pengolahan Data

Dari tabel di atas diketahui bahwa koefisien determinasi menunjukkan nilai $R$ square sebesar 0,124 . Hal ini berarti $12,4 \%$ variasi perubahan nilai perusahaan dapat dijelaskan oleh kepemilikan manajerial, kebijakan dividen, leverage dan ukuran perusahaan serta interaksi kebijakan manajerial dan kebijakan dividen, sisanya $87,6 \%$ perubahan nilai perusahaan dipengaruhi faktor lain diluar model penelitian.

b. $\quad$ Nilai $F$

Hasil uji nilai F statistik tersaji pada tabel berikut ini.

Tabel 9

Nilai F Regresi 2

\begin{tabular}{llllll}
$\begin{array}{l}\text { Mode } \\
1\end{array}$ & $\begin{array}{l}\text { Sum } \\
\text { Squares }\end{array}$ & of & $\begin{array}{l}\text { Mean } \\
\text { Square }\end{array}$ & F & Sig. \\
\hline 1 & 38.445 & 5 & 7.689 & 9.003 & 0.000 \\
& 236.579 & 277 & 0.854 & & \\
& 275.025 & 282 & & & \\
\hline
\end{tabular}

Sumber: Hasil Pengolahan Data

Nilai F regresi bertujuan untuk menguji tingkat fit model penelitian (Ghozali 2005). Hasil uji nilai $\mathrm{F}$ menunjukkan nilai $\mathrm{F}$ sebesar 9,003 dengan nilai $\mathrm{p}$ sebesar 0,000 , sehingga dapat disimpulkan bahwa model penelitian ini telah fit dengan data yang digunakan.

c. Nilai $t$

Hasil uji nilai t statistik tersaji pada tabel berikut ini.

Tabel 10

Nilai t Regresi 2

\begin{tabular}{llllll}
\hline Variabel & $\begin{array}{l}\text { Koefisien } \\
\text { Regresi }\end{array}$ & $\begin{array}{l}\text { Standar } \\
\text { Error }\end{array}$ & $\begin{array}{l}\text { Koefisien } \\
\text { Korelasi }\end{array}$ & $\begin{array}{l}\mathrm{t} \\
\text { hitung }\end{array}$ & Nilai $\mathrm{p}$ \\
\hline (Constant) & -1.956 & 1.000 & & -1.955 & .052 \\
KM & -0.920 & 0.726 & -0.087 & -1.268 & 0.206 \\
DUMDIV & 0.528 & 0.133 & 0.267 & 3.978 & 0.000 \\
KM*DUMDIV & -2.139 & 1.282 & -0.117 & -1.669 & 0.096 \\
LNLEV & 0.077 & 0.091 & 0.050 & 0.843 & 0.400 \\
LNSIZE & 0.071 & 0.036 & 0.124 & 1.962 & 0.051 \\
\hline
\end{tabular}

Sumber: Hasil Pengolahan Data

Hipotesis 2 dalam penelitian ini bertujuan untuk menguji peran kebijakan dividen sebagai variabel moderasi dalam pengaruh kepemilikan manajerial terhadap nilai perusahaan. Hasil uji regresi menunjukkan koefisien regresi sebesar sebesar -2,139 dengan nilai p sebesar 0,096. Hipotesis 2 tidak didukung pada tingkat signifikansi 5\% namun didukung pada tingkat 
signifikansi $10 \%$. Peran kebijakan dividen sebagai variabel moderasi terbukti pada tingkat signifikansi $10 \%$ sehingga dapat disimpulkan bahwa kebijakan dividen merupakan variabel moderasi yang memperlemah efek negatif kepemilikan manajerial terhadap nilai perusahaan. Hipotesis 2 didukung pada tingkat signifikansi 10\%. Variabel kepemilikan manajerial yang pada regresi persamaan 1 yang pada awalnya berpengaruh negatif signifikan menjadi tidak berpengaruh dalam regresi persamaan 2. Koefisien regresi pada variabel kepemilikan manajerial juga menjadi lebih kecil pada regresi persamaan 2. Hal ini menunjukkan adanya kebijakan dividen yang dilakukan oleh manajemen perusahaan akan mengurangi efek negatif kepemilikan perusahaan terhadap nilai perusahaan meskipun dalam penelitian ini hanya terbukti pada tingkat signifikansi $10 \%$.

Solong dan Nor (2010) menyebutkan dividen dapat meningkatkan komunikasi dan kordinasi dalam perusahaan sehingga dapat mengurangi biaya keagenan dan meningkatkan nilai perusahaan. Osman dan Muhammed (2010) berpendapat bahwa pembayaran dividen yang meningkat dianggap sebagai sinyal yang baik akan kondisi perusahaan serta menunjukkan prospek akan profitabilitas perusahaan yang tinggi di masa depan. Dividen memiliki atau mengandung sinyal informasi atas kondisi keuangan perusahaan. Semakin besar dividen yang dibagikan kepada pemegang saham, maka kinerja perusahaan akan dianggap semakin baik, dan pada akhirnya penilaian terhadap perusahaan yang tercermin melalui harga saham akan semakin baik pula (Mahendara et al., 2012).

Menurut Nurhyati (2013) kebijakan dividen yang diambil perusahaan pada dasarnya adalah penentuan berapa bagian keuntungan yang diperoleh perusahaan yang akan dibagikan kepada pemegang saham. Kebijakan dividen berpengaruh positif terhadap nilai perusahaan. Pasar bereaksi negatif terhadap kepemilikan manajerial yang besar, namun reaksi tersebut akan menjadi berbeda jika perusahaan membayarkan dividen. Pasar bereaksi positif dengan adanya kebijakan dividen dan mengurangi dampak negatif kepemilikan manajerial terhadap nilai perusahaan. Peran kebijakan dividen sebagai variabel moderasi dalam penelitian ini terbukti meskipun dengan tingkat signifikansi yang lebih besar yaitu 10\%. Hasil penelitian ini mendukung hasil penelitian Sulong dan Nor (2010) serta Atmaja (2009), yang menyatakan bahwa kebijakan dividen menjadi hal yang sangat penting yang berdampak positif terhadap nilai perusahaan. Semakin besar dividen yang dibayarkan perusahaan maka akan semakin besar pula nilai perusahaan.

\section{KESIMPULAN}

Penelitian ini bertujuan menguji pengaruh kepemilikan manajerial terhadap nilai perusahaan dengan kebijakan dividen sebagai variabel moderasi pada perusahaan manufaktur yang terdaftar di Bursa Efek Indonesia. Berdasar analisis dan pembahasan pada bab sebelumnya maka peneliti mengambil kesimpulan sebagai berikut.

1. Kepemilikan manajerial berpengaruh negatif terhadap nilai perusahaan. Hasil penelitian mendukung hasil penelitian Haruman (2008). Pasar bereaksi secara negatif atas kepemilikan manajerial yang besar dalam perusahaan.

2. Kebijakan dividen terbukti sebagai variabel moderasi pada tingkat signifikansi $10 \%$ dalam hubungan antara kepemilikan manajerial dan nilai perusahaan. Adanya kebijakan dividen akan memperlemah hubungan negatif antara kepemilikan manajerial dan nilai perusahaan. Hasil penelitian ini mendukung hasil penelitian Atmaja (2009).

\section{Saran}

1. Penelitian selanjutnya disarankan untuk memperpanjang perioda penelitian serta memperluas sampel penelitian dengan sampel diluar perusahaan manufaktur misalnya perusahaan perbankan. 
Wahyu Budianto Dan Payamta : Pengaruh Kepemilikan Manajerial Terhadap ...

2. Penelitian selanjutnya disarankan untuk menguji variabel lain yang diduga berpengaruh terhadap nilai perusahaan seperti kepemilikan institusional, kepemilikan bank, kepemilikan asing, struktur modal, dan pelaksanaan corporate governance.

\section{DAFTAR PUSTAKA}

Abdullah, Norhasniza Mohd Hasan, Zuraidah Ahmad dan Shashazrina Roslan. The Influence of Ownership Structure on the Firms Dividend Policy Based Lintner Model. International Review of Business Research Papers Vol. 8. No.6. September 2012, pp. $71-88$.

Almilia, Luci. S dan Lailul.L Sifa. 2006. Reaksi Pasar Publikasi Corporate Governance Perseption Index Pada Perusahaan yang Terdaftar di Bursa Efek Jakarta. SNA IX: Ikatan Akuntan Indonesia.

Atmaja, Lukas Y. Setia. 2009. Governance Mechanisms and Firm Value: The Impact of Ownership Concentration and Dividends. Corporate Governance: An International Review, Vol. 17, pp. 694-709

Benson, Bradly.W and Wallace N. Davinson. 2008. Reexamining the Managerial Ownership Effect on Firm Value. Available on line at www.ssrn.com, diunduh 5 Maret 2013.

Brigham dan Houston. 2006. Dasar-Dasar Manajemen Keuangan. Edisi Kesepuluh. Jakarta : Salemba Empat

Christiawan, Yulius Jogi dan Josua Tarigan. 2004. Kepemilikan Manajeral: Kebijakan Hutang, Kinerja dan Nilai Perusahaan. Available on line at www.petra.ac.id, diunduh 5 Maret 2013.

Dharmastuti, Ch.Fara, Katarina Stella dan Eviyanti. 2003. Analisis Keterkaitan Secara Simultan Antara Kebijakan Dividen Dan Kebijakan Hutang Pada Perusahaan Yang Terdaftar Di Bursa Efek Jakarta Periode Tahun 2000-2002. Available online at www.google.co.id, diunduh 5 Maret 2013.

Fahlenbrach, Rudiger dan Rene M. Stulz. 2007. Managerial Ownership Dynamics and Firm Value. Nber Working Paper Series.

Fama, Eugene F and French, Kenneth R, 1998, Taxes, Financing Decision, and Firm Value, The Journal of Finance; Vol. LIII No. 3, June, pp. 819-843

Iturriaga, Félix J. López dan Vicente Lima Crisóstomo.2010. Do Leverage, Dividend Payout, and Ownership Concentration Influence Firms' Value Creation? An Analysis of Brazilian Firms. Emerging Markets Finance \& Trade. Vol. 46, No. 3, pp. 80-94.

Ghozali, Imam. 2009. Ekonometrika; teori, Konsep dan Aplikasi dengan SPSS 17. Badan Penerbit Undip: Semarang.

Haruman, Tendi. 2008. Pengaruh Struktur Kepemilikan Terhadap Keputusan Keuangan Dan Nilai Perusahaan Survey pada Perusahaan Manufaktur di PT. Bursa Efek Indonesia. SNA XI : Ikatan Akuntan Indonesia.

Hermuningsih, Sri, Dwiproptono Agus H, dan Dewi Kusuma W.2008. The Influence of Insider Ownership, Dividen Policy and Debt Policy to The Firm Value at 
Companies Which are Enlisted in Indonesia Stock Exchange. Avalable on line at www.google.com.

Ismiyanti, Fitri dan Hanafi, Mamduh.H. 2003. Kepemilikan Manajerial, Kepemilikan Institusional, Risiko, Kebijakan Utang Dan Kebijakan Dividen: Analisis Persamaan Simultan. SNA VI : Ikatan Akuntan Indonesia.

Jensen, M. C. 1986. Agency Costs and Free Cash Flow, Corporate Finance and Takeovers. American Economic Review, Vol. 76, pp. 659-665.

Jensen, Michael C; dan W.H. Meckling. 1976. Theory of The Firm: Managerial Behavior, Agency Cost and Ownership Structure. Journal of Financial Economics. Vol. 3 Issue 4 (October), pp. 305-360.

Lee, Sang Mook dan Keunkwan Ryu. 2003. Mangerial Ownership and Firm,s Value: An Empirical Analysis using Data Panel. Avalable on line at www.iser.osaka-u.a.jp. diunduh 5 Maret 2013.

Mahendra, Alfredo. 2011. Pengaruh Kinerja Keuangan Terhadap Nilai Perusahaan (Kebijakan Dividen Sebagai Variabel Moderating) Pada Perusahaan Manufaktur Di Bursa Efek Indonesia. Tesis Universitas Udayana; Tidak dipublikasikan.

Mahendra, Alfredo, Luh Gede Sri Artini dan A.A Gede Saurjaya. 2012. Pengaruh Kinerja Keuangan Terhadap Nilai Perusahaan Pada Perusahaan Manufaktur di Bursa Efek Indonesia. Jurnal Manajemen, Strategi Bisnis, Dan Kewirausahaan. Vol. 6 No.2.

Ngui, Kwang Sing, Mung ling V, Eidith. A.L. 2007. The effects of insider and blockholder ownerships on firm performance: the mediating role of internal governance mechanisms. Avalable on line at www.ssrn.com, diunduh 5 Maret 2013.

Nurhayati, Mafizatun. 2013. Profitabilitas, Likuiditas dan Ukuran Perusahaan Pengaruhnya Terhadap Kebijakan Dividend dan Nilai Perusahaan Perusahaan Non Jasa. Jurnal Keuangan dan Bisnis. Vol. 2, pp. 144-153.

Olweny, Tobias. 2012. Dividend Announcement and Firm Value: A Test of Semi Strong Form of Efficiency at the Nairobi Stock Exchange. Asian Social Science, Vol. 8, No. 1; January 2012.

Osman, Dialdin dan Elsaudi Mohammed. 2010. Dividend Policy in Saudi Arabia. The International Journal of Business and Finance Research, Vol 4.

Santoso, Singgih. 2000. SPSS Statistik Parametrik. PT. Elex Media Komputindo: Jakarta.

Siallagan, Hamonangan dan Mas'ud Machfoed. 2006. Mekanisme corporate governance, kualitas laba dan nilai perusahaan. SNA IX : Ikatan Akuntan Indonesia.

Silvera, alexandre, Lucas aryes and C. Barros. 2007. Corporate Governance Quality and Firm Value in Brazil. Avalable on line at www.ssrn.com. diunduh 5 Maret 2013.

Soliha, Euis, dan Taswan, 2002. Pengaruh Kebijakan Hutang terhadap Nilai Perusahaan serta Beberapa Faktor yang Mempengaruhinya. Jurnal Bisnis dan Ekonomi, September, pp. 1-17. 
Sulistiono. 2010. Pengaruh Kepemilikan Manajerial, Struktur Modal dan Ukuran Perusahaan Terhadap Nilai Perusahaan Pada Perusahaan Manufaktur Di BEI Tahun 2006-2008. Penelitian FE Universitas Negeri Semarang; Tidak di publikasikan.

Sulong, Zunaidah dan Fauzias Mat Nor. 2010. Corporate governance mechanisms and firm valuation in Malaysian listed firms: A panel data analysis. Journal of Modern Accounting and Auditing, ISSN 1548-6583, USA. Jan. 2010, Vol.6, No.1 (Serial No.56).

Wahyudi dan Parwestri, Hartini.P. 2006. Implikasi struktur Kepemilikan Terhadap Nilai Perusahaan dengan keputusan keuangan sebagai variabel intervening. SNA IX: Ikantan Akuntan Indonesia.

Wardhani, Ratna. 2006. Mekanisme Corporate governance dalam Perusahaan yang Mengalami Masalah Keuangan. SNA 9 : Ikatan Akuntan Indonesia.

Wu, Lingling. 2004. The Impact of Ownership Structure on Debt Financing of Japanese Firms With the agency cost of Free Cash Flow. Available on line at www.ssrn.com, diunduh 5 Maret 2013. 